\title{
Brief on Solar Concentrators: Differences and Applications
}

\author{
Mokhtar Ghodbane $^{1 *}$, Djamel Benmenine ${ }^{2}$, Abderrahmane Khechekhouche ${ }^{3}$, Boussad Boumeddane ${ }^{1}$ \\ ${ }^{1}$ Department of Mechanical Engineering, Faculty of Technology, Saad Dahlab University of Blida 1, Blida 09000, Algeria \\ ${ }^{2}$ Laboratory for the Development of New and Renewable Energies in Arid Zones (LENREZA), Kasdi Merbah University of \\ Ouargla, Ouargla 30000, Algeria \\ ${ }^{3}$ Algeria Department of Mechanical Engineering, Faculty of Technology, El-Oued University, El-Oued 39000, Algeria
}

Corresponding Author Email: m_ghodbane@univ-blida.dz

https://doi.org/10.18280/i2m.190507

Received: 17 July 2020

Accepted: 22 September 2020

\section{Keywords:}

renewable energy, solar energy, point solar concentrators, linear solar concentrators

\begin{abstract}
In light of the global crises that the world suffers from, the renewable energy exploitation is a viable solution to remedy the various energy crises, knowing that renewable energy is a source of environmental credibility, as it does not cause any pollution or any emissions harmful to the environment. Among the most important renewable energy sources, solar energy is the most important type as it can be exploited thermally by adopting various solar collectors, especially solar concentrators. This paper has been devoted to illustrate the types of solar concentrators, namely point-focus concentrators (Heliostat Field Collectors and Parabolic Dish Collectors) and linear concentrators (Linear Fresnel Reflectors and Parabolic Trough Collectors), in an attempt to clarify its principle and its multiple uses domestically and industrially, especially in areas that are characterized by the abundance of its direct solar radiation. The solar concentrator is a solar thermal energy concentration system, because its use reduces the consumption of fossil fuels harmful to the environment and directly contributes to climate change. Solar thermal concentrators are an effective alternative to fossil generators for thermal energy, as they have many important uses such as the solar electricity production of solar electricity in power plants, industrial and domestic water heating, and have many other industrial uses.
\end{abstract}

\section{INTRODUCTION}

In view of the strong global demand for energy for multiple needs in many fields and in an effort to preserve the environment from pollution and harmful emissions, the necessity of finding clean alternative energy sources has become a very important priority and a goal in the primary for the advancement of sustainable development and global energy transformation. Therefore, in order to achieve global energy sufficiency with environmentally friendly foundations, renewable energy is the most important alternative sources [1$3]$, as they are the core of the energy transformation from traditional sources to clean and environmentally friendly renewable sources that are characterized by their sustainable nature.

Solar energy is the most important source of renewable energy, where it can be exploited thermally and photovoltaically by using multiple solar collectors [4], Knowing that, the performance of solar collectors can be improved by dispersing nanoparticles within the working fluid [5-9], because the dispersed nanoparticles inside the working fluid improve the thermal transfer coefficients of the base fluid [10]. There are several techniques for using solar energy thermally, the most important of which is the use of thermodynamic systems with solar concentrators that are considered the most important in the world [9, 11-14], as these systems generate solar energy using mirrors or lenses to focus a large amount of beam radiation on a small area in order to exploit the heat flux intensity later in several industrial applications such as electricity production $[14,15]$, heating water [8, 16-19], water desalination and purification [6], cooling and air conditioning systems [20,21], industrial uses [22-24] and agricultural applications [25]. For example, solar electricity is generated when the concentrated solar radiation is converted into heat [26], which drives a steam turbine connected to an electric power generator or a thermochemical reaction [27-29].

Thermodynamic systems with solar concentrators depend on the use of a set of reflective mirrors that direct the beam radiation towards an absorber tube or a point focus through which the working fluid passes. Then, the heat is transferred to the working fluid by convection. To achieve this, reflective mirrors must follow the movement of the sun daily from sunrise to sunset in order to focus direct solar radiation on a point and linear focus, and then a convective heat exchange occurs between the receiver interior wall and the fluid that moves inside. As shown in Figure 1, the most promising sites for the establishment of concentrated thermodynamic solar power plants are very numerous, they are particularly located in North Africa, in the Mediterranean countries, in the Near and Middle East, in Australia, in the South-West of the United States. United, India or Central Asia.

Thermodynamic systems with solar concentrators cover all technologies aimed at converting direct normal irradiance "DNI, (W.m-2)" to a high temperature by specific solar concentrators, and then this high heat is exploited in several areas the most important of which is electricity production. Generally, solar concentrators are divided into two categories: 
- Point solar concentrators;

- Linear solar concentrators.

This study aims to briefly define the families of the various solar concentrates, which are known to be widely used globally in many areas, both domestic and industrial.

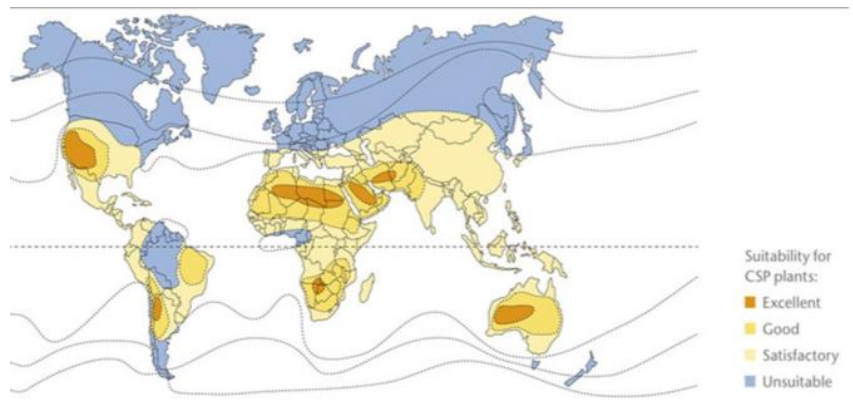

Figure 1. Map of suitable areas for concentrated thermodynamic solar power plants [30]

\section{SOLAR CONCENTRATORS}

The solar concentration origin goes back to a very old time when it was used by the Greeks in the $8^{\text {th }} \mathrm{BC}$, to light the first torch of the ancient Olympic games (776 BC) [31], where it was illuminated by sunlight using the parabolic mirror (SKAPHIA). Five centuries later, coinciding with the attack of the Romans and their siege of Syracuse (Sicily), Archimedes had reused the fire mirror invention (Figure 2), since he had developed giant polished bronze mirrors to reflect the sun rays and then focused on the Roman fleet ships to burn its sails. In Europe (1515), Leonardo da Vinci proposed the idea of designing a Compact Linear Fresnel Reflector (CLFR), but according to what has been reported in the literature, his study of this system remained only an idea on paper and was not supported by experimental work [31], as he said that this system is valid for many industrial uses [32]. Almost 450 years after its invention by Leonardo da Vinci (exactly in 1963), the first CLFR (Compact Linear Fresnel Reflector) system was installed by Giovanni Francia and Marcel Perrot in Marseille.

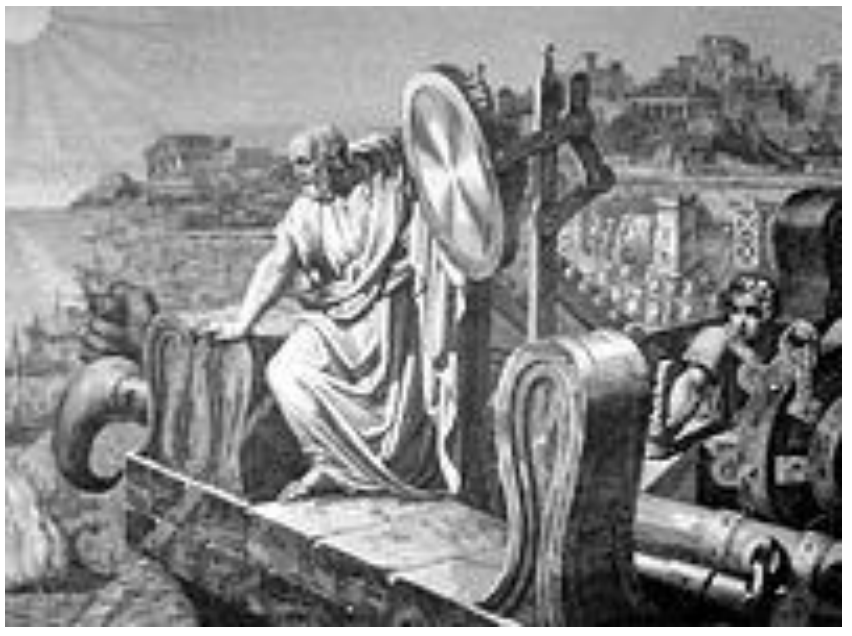

Figure 2. One of Archimedes' fiery mirrors [33]

In order to melt metals at $1800^{\circ} \mathrm{C}$, Antoine Laurent de Lavoisier invented a solar furnace made up of converging lenses in 1774 (Figure 3).
Moreover, Horace Bénédict de Saussure in the 1780s invented the sun-thermometer (HELIOTHERMOMETER) to study the calorific effects of the sun's rays [31]. It looks like hot boxes with insulated walls and one or more stained glass windows. In addition, he thus creates the first thermal solar collectors at low temperature.

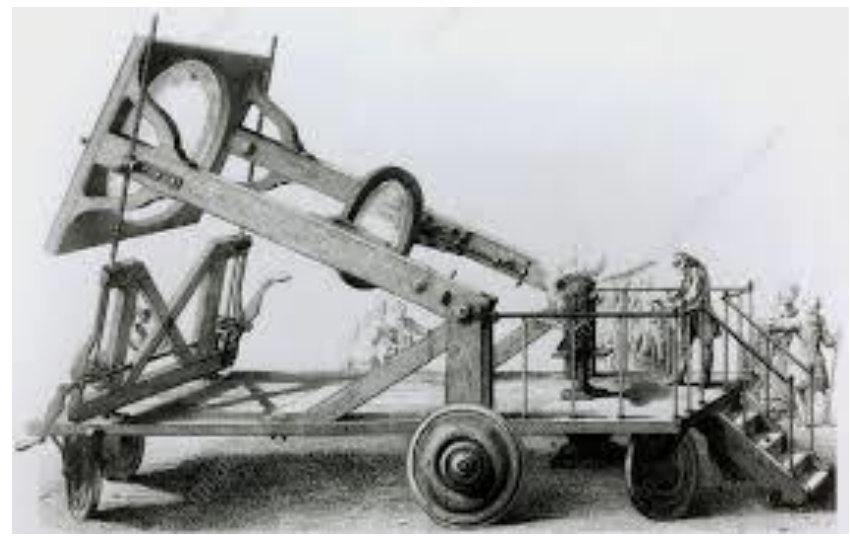

Figure 3. Antoine Laurent de Lavoisier's solar furnace [34]

In addition, the hot air engine was invented by Robert Stirling in 1816, where today it is called the 4-stroke Stirling engine [35].

Augustin Mouchot developed many inventions during the XIXth century such as solar distillation, solar cooking, solar pasteurization, solar pumping and the parabolic concentrator feeding thermal machines, where he won the gold medal at the Universal Exhibition of 1878 with a solar reflector (5 meters in diameter) associated with a steam engine which operates a printing press [25].

Also, the physicist James Dewar in 1893 discovered the thermos effect according to the vacuum flask principle with two walls separated by an air space in order to ensure almost perfect insulation [36], where this principle subsequently allowed the development of solar collectors. thermal vacuum tubes.

From 1906 to 1911, Frank Shuman designed some solar engine, while the physicist Charles Vernon Boys designed and implemented a parabolic trough collector in 1912. As shown in Figure 4, F. Shuman and Charles Vernon Boys built an industrial-scale thermo-solar plant in Egypt (in 1913) to electrify the watering pumps [25].

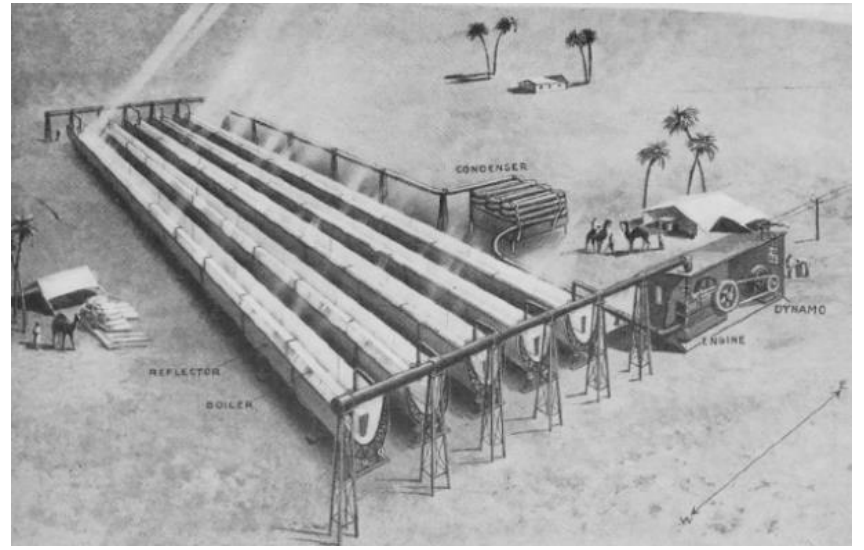

Figure 4. Solar Irrigation Installation for Shuman-Boys (Egypt 1913) [37] 
In 1949, Félix Trombe built in Mont Louis a solar oven (huge parabolic mirror) in Mont-Louis with a power of $50 \mathrm{~kW}$ which allows to reach $3000^{\circ} \mathrm{C}$ at its point of concentration [38]. Then, F. Trombe designed a large-scale solar furnace in the world at Font-Romeu-Odeillo-Via between 1962-1968.

In 1983, Electricity of France (EDF) inaugurated the first French tower power plant (THÉMIS solar plant (Figure 5)), but because of France having chosen to develop only the nuclear sector, this solar station closed in 1986 [39], to reopen in 2004 as a research and development center dedicated to solar energy.

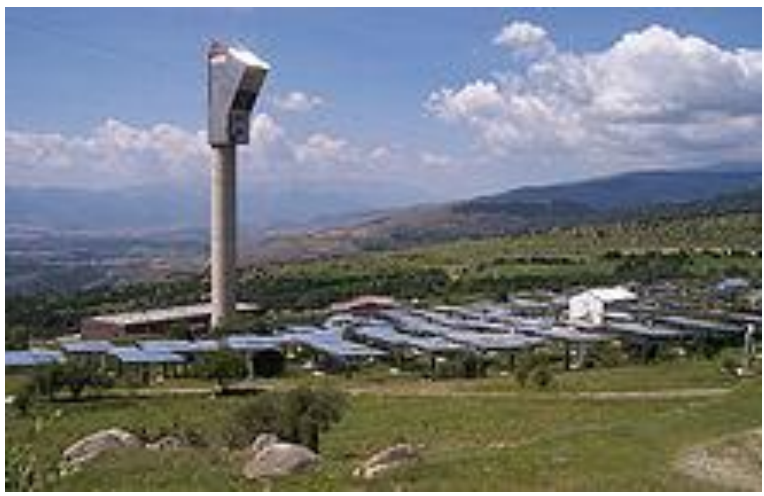

Figure 5. THÉMIS solar power plant in France (42॰30’05” $\mathrm{N}, 1^{\circ} 58$ '27’ E) [40]

At the end of the twentieth century, many solar power plants and solar furnaces were launched in many parts of the world, as numerous parabolic trough collector power plants were created in the United States between 1985 to 1991 [3].

Therefore, solar energy concentration allows to obtain very practical temperatures suitable for use in many domestic and industrial fields, where the concentrated solar technology is of great interest as it is an efficient and adequate way to meet the ever-growing demand for solar electricity on a global scale. The solar concentrators receive beam radiation using a perfectly reflective surface and a tracking system, then direct it to a reduced surface receiver by refractions through prisms or lenses or through multiple reflections on mirrors.

All the technologies used in concentrated solar power are based on the two modes of point and linear concentration. So, there are four mainly developed technologies which are represented as follows:

- Heliostat field collectors (HFCs);

- Parabolic dish collectors (PDCs);

- Linear Fresnel solar reflectors (LFRs);

- Parabolic trough collectors (PTCs).

\subsection{Point solar concentrators}

\subsubsection{Heliostat field collectors (HFCs)}

As shown in Figure 6, the heliostat field collectors (HFCs) consists of thousands of reflective mirrors equipped with a sun tracking system in two axes of rotation to focus the beam radiation on a central receiver placed at the top of the tower [2, $3,41]$.

This type of thermal power plant displays four types classified according to the energy production mode as well as the working fluid used [42], they are:

- Atmospheric air system;

- Hybrid pressurized air system;
- Indirect steam production system with molten salt as working fluid;

- Direct steam production system with water/steam as working fluid.

The major advantages of this technology are:

- The fairly acceptable conversion efficiency due to the high temperatures reached at the HFC focal point;

- A very noticeable reduction in thermal losses to the environment is displayed due to the limited reflection surface of the heliostats;

- The possibility of coupling the capture of solar energy to an energy storage device in the form of sensible heat.

On the other hand, tower plants with molten salts have the disadvantage mainly due to the high solidification temperature of the molten salts (about $255^{\circ} \mathrm{C}$ ), where this imposes a permanent heat supply to the pipes of the low temperature network in order to avoid the problems caused by solid plugs.

This technology is known to be one of the most promising technologies for solar power generation in the mid-power range. These systems have already proven their ability to generate clean electricity with a size of 20 MWe in Spain, while the SPT plant with $100 \mathrm{MWe}$ is under construction in the United States [43]. Based on the studies reported in the literature, the heat fluid for this technique varies between 150 and $2000^{\circ} \mathrm{C}$ [44]. Regarding the progress in HFCs development, Pfahl et al. discussed it in detail in their valuable paper [42].

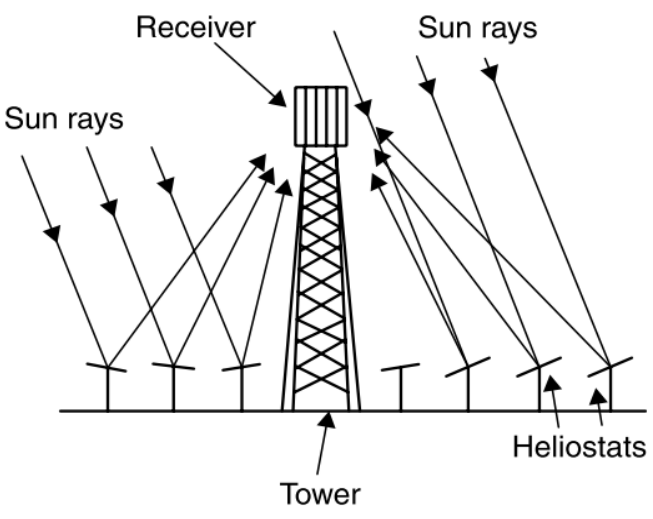

Figure 6. Heliostat field collector schematic [2, 3]

\subsubsection{Parabolic dish collectors (PDCs)}

As for the parabolic dish collectors (PDCs), they are small solar energy conversion units compared to other CSP systems (HFCs, PTCs and LFRs) [2, 3]. The typical PDC system sizes are generally between $5 \mathrm{~kW}$ and $25 \mathrm{kWe}$. Figure 7 illustrates a PDC solar collector. For information, the largest parabolic dish collector has been designed and implemented in Australia with a reflective surface of $489 \mathrm{~m}^{2}$ and a focal length of 13.4 meter. The major advantages of PDCs technology are:

- Possibility of installation on all types of ground without flatness constraint of the ground;

- Strong adaptation to stand-alone and isolated applications;

- Modularity of the system and possibility of integrating thermal storage with high efficiency; 
- It has a high conversion efficiency compared to all types of concentrating solar systems (point and linear).

But the investment and operation costs are somewhat high compared to other types of solar concentrators. In addition, the permanent focusing of the solar spot at the PDC focus requires very suitable positioning and regulation, which in the event of failure causes a rapid drop in PDC efficiency.
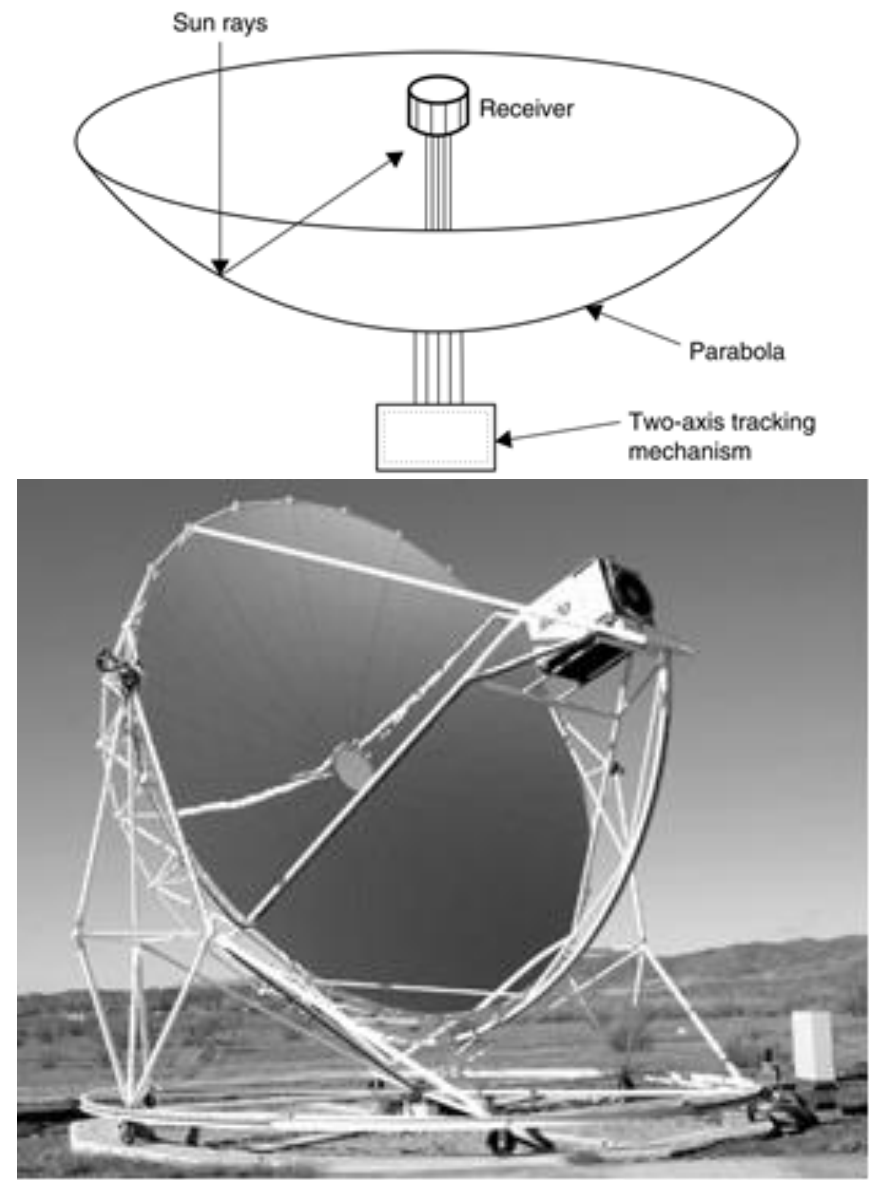

Figure 7. Parabolic dish collector schematic [2, 3]

The PDC local concentration ratio (LCR) in the absorber point is very important and has a significant role in total thermal performance of the PDC system. For this reason, the proper design of this focal point and the good choice of its location are very important and vital factor. Therefore, many recent scientific studies focus on improving the focus point design of the PDC $[45,46]$. In addition, the PDC technology can be connected with Stirling engine, where Advanco Corporation developed Dish/Stirling solar concentrating technology between 1984 and 1988. While the $25 \mathrm{~kW}$ Dish/Stirling system is developed by McDonnell Douglas Aerospace Corporation (MDA), the $50 \mathrm{~kW}$ system and $9 \mathrm{~kW}$ system are developed by Schlaich Bergermann and Partner (SBP) [46]. Based on the studies reported in the literature, the heat fluid for this point receivers varies between 100 and $1500^{\circ} \mathrm{C}$ [44]. Generally, the PDC has been used as a heat generator for Stirling engines, where its reflective surface focuses direct solar rays from the sun into the point focus. One of the major constraints facing the PDC operation is the permanent orientation towards the direction of the sun, which requires their mobilization along both azimuthal and vertical axes in order to follow the course of the sun. The PDC size is determined through the power required by the Stirling engine.
Regarding Stirling engines, they are classified into three categories:

- Alpha engines: they have two separate cylinders, in each of which there is a hermetic piston. The variations in hot and cold volumes are created separately by the movements of separate pistons;

- Beta engines in which the displacement piston and the working piston are in tandem (in the same body), as the cycle is accomplished by the combined action of the two pistons;

- The gamma engine is an assembly of the previous two engines (Alpha and Beta), where it consists of two cylinders as in the alpha engine but the variable volumes (hot and cold) are created in the same way as in the beta engine.

Concerning the PDCs uses in concentrating solar power, Coventry and Andraka touched on it in detail in their sober paper [47].

\subsection{Linear solar concentrators}

\subsubsection{Linear Fresnel solar reflectors (LFRs)}

As shown in Figure 8, the LFR operating principle lies in its flat mirrors, where each of these mirrors can be rotated following the sun path to constantly redirect and focus the beam radiation towards a receiver pipe, as the working fluid is heated while circulating in this horizontal tube $[5,48]$.

This technology is named after the French scientist Augustin-Jean Fresnel, who invented Fresnel's objective in the eighteenth century for lighthouses $[19,49,50]$. His idea was to grind a conventional convex lens on a multi-section lens to obtain a cheaper and lighter lens, which can send the light rays correctly in a given direction $[19,49,50]$. The main idea of the LFR technology was inspired by the Fresnel lens to divide a parabolic mirror into a series of reflecting mirrors to focus the collimated rays on a focal point or line, depending on whether the reflectors are circular or linear.

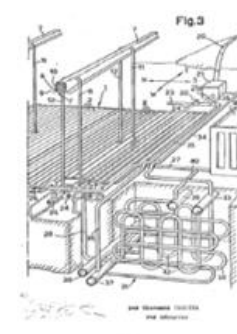

(a)

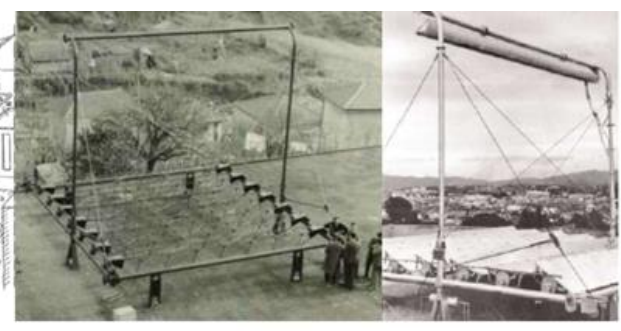

(b)

(c)
Figure 8. First LFR prototype of Francia: a) Design of the LFR patent, patent $\mathrm{N}^{\circ} 18634$. b) LFR building in Italy, c) LFR tests in France [20]

The history of the first LFR prototype dates back to 1962 before Giovanni Francia filed a patent for technology in 1963 in Italy. The first LFR prototype was built in Genoa and tested a year later at the solar station of Lacedaemon-Marseille, France by Francia and her colleagues. Figure 9 shows the LFR solar power plant integrated into an urban context circa 1965 that was drawn by Francia [49].

However, the story of the first large-scale study of LFR dates back to the late 1960s when Francia and her colleagues worked on the Solar City Project - Hypothesis for an Urban Structure. This project aimed to use solar energy for electricity 
generation and cooling and space heating for an urban area of about 105 inhabitants [20, 49].

Generally, the reflective flat mirrors of LFR solar reflectors are much cheaper than parabolic mirrors, and the mechanical stresses imposed by the wind thrust are reduced by the flat arrangement of the mirrors. The only drawback to this technology is its low-quality efficiency compared to other types of solar concentrators $[5,8,22,51,52]$. Based on the studies reported in the literature, the heat fluid for this solar concentrator varies between 60 and $250^{\circ} \mathrm{C}$ [40], whereas, Bellos has touched in his very valuable scientific paper the most important differences between LFRs and PTCs collectors, and he explained the most important uses of LFR solar reflectors [22].
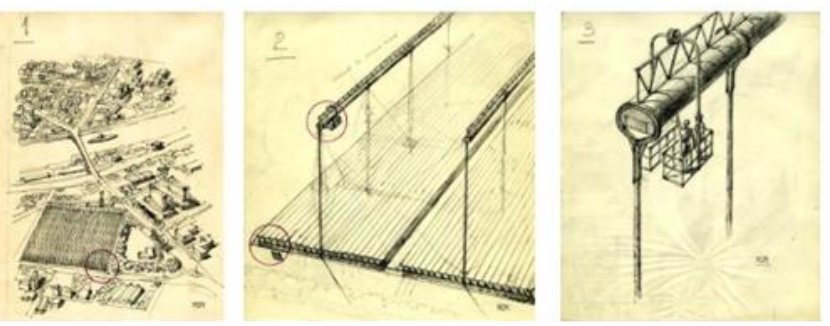

Figure 9. Scheme of LFR solar power plant by Francia [49]

\subsubsection{Parabolic trough collectors (PTCs)}

Parabolic Trough Collectors (PTCs) are long parallel rows of curved glass mirrors concentrating beam radiation onto a receiver pipe located along its focal line $[18,50,53]$. The first practical experience with the parabolic trough concentrator dates back to 1870, when engineer John Ericsson designed and built a PTC collector with a surface area of $3.25 \mathrm{~m}^{2}$ that was driving a small $373 \mathrm{~W}$ engine $[24,54]$.

From 1872 to 1875 , John Ericsson built seven similar systems, but with air as working fluid [24, 25]. As shown in Figure 10, John Ericsson built a large solar engine in 1883 that was exhibited in New York $[24,25,55]$. It consisted of a PTC with $3.35 \mathrm{~m}$ long and $4.88 \mathrm{~m}$ wide, focusing solar radiation on a boiler tube with $15.88 \mathrm{~cm}$ in diameter. The concentrator consisted of straight wooden moats, supported by curved parabolic iron ribs attached to the sides of the bowl. The reflective plates made of flat-silvered glass on the underside, were attached to these moats.

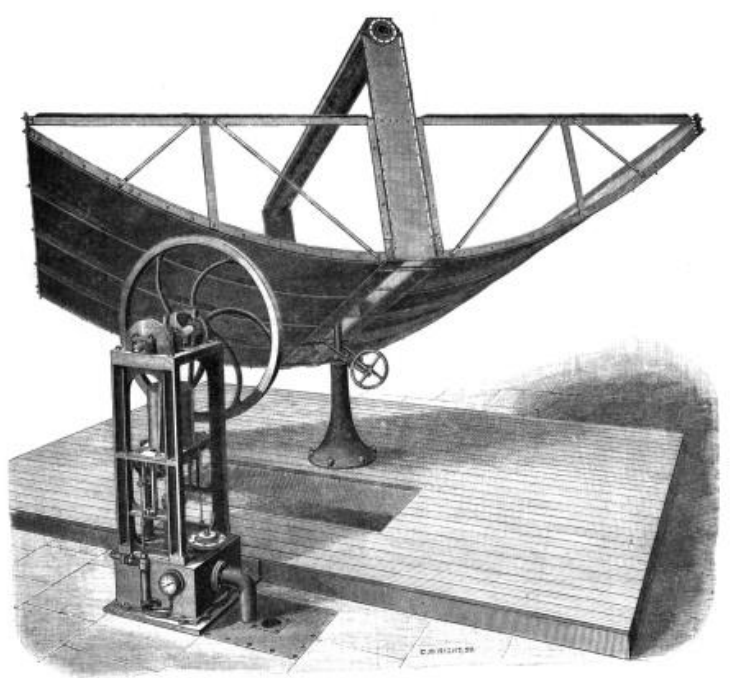

Figure 10. The solar engine of Ericsson [55]
The entire apparatus has followed the sun for this purpose is manually operated. The average engine speed during the summer tests was $120 \mathrm{rpm}$ and the absolute working pressure of the piston was $0.24 \mathrm{MPa}[24,55]$. In 1886, John Ericsson experimented a solar engine with a $1.86 \mathrm{~kW}$. Ericsson refused to give technical details about the boilers for protection reasons. Unfortunately, he died in 1889 before finishing the commercial version of his sun engine, and his project was never pursued $[24,55]$. Based on the studies reported in the literature, the heat fluid for these linear collectors varies between 60 and $300^{\circ} \mathrm{C}$ [44]. Regarding PTCs applications, Fernández-Garcí et al. discussed them in great detail in their serious work [56].

So far, the operating renewable energy cost is very high, so the production costs and the efficiency of the product must be agreed in order to have an efficient device with an acceptable price. As for the parabolic trough solar collectors, the design cost is high compared to LFR technology because it relies on the glass shaping to obtain the parabolic form of the reflecting mirror. Therefore, the use of flat reflector mirrors will significantly reduce the cost of manufacturing linear solar reflectors. For this reason, much of the scientific research has been directed towards the development of the linear Fresnel Solar reflectors (LFRs) systems, and many countries such as Spain and Germany have widely exploited this technology of acceptable price, knowing that its efficiency is relatively low compared to the PTCs solar concentrators systems. Table 1 illustrates a comparison of different solar concentrators.

Table 1. Differences between solar concentrators [3]

\begin{tabular}{cccc}
\hline $\begin{array}{c}\text { Solar } \\
\text { collector }\end{array}$ & $\begin{array}{c}\text { Axis } \\
\text { tracking }\end{array}$ & $\begin{array}{c}\text { Local concentration } \\
\text { ratio }\end{array}$ & $\begin{array}{c}\text { Temperature range } \\
\left({ }^{\circ} \mathbf{C}\right)\end{array}$ \\
\hline HFCs & Tow- & From 300 to 1500 & From 150 to 2000 \\
PDCs & axis & From 600 to 2000 & From 100 to 1500 \\
LFRs & Single- & From 10 to 40 & From 60 to 250 \\
PTCs & axis & From 10 to 85 & From 60 to 400 \\
\hline
\end{tabular}

One of the most important uses of solar concentrators is to produce thermal electricity, as shown in Table 2.

Table 2. Comparison of thermal solar power plants [7]

\begin{tabular}{|c|c|c|c|c|}
\hline $\begin{array}{c}\text { Solar } \\
\text { collector }\end{array}$ & $\begin{array}{c}\text { Capacity } \\
\text { (MW) }\end{array}$ & $\begin{array}{c}\text { Power plant } \\
\text { performance }(\%)\end{array}$ & Cost & Power cycle \\
\hline HFCs & $\begin{array}{l}\text { From } 10 \\
\text { to } 100\end{array}$ & From 10 to 22 & High & $\begin{array}{c}\text { Gas turbine } \\
\text { Bryton cycle \& } \\
\text { Steam Rankine. }\end{array}$ \\
\hline PDCs & $\begin{array}{l}\text { From } \\
0.01 \text { to } 1\end{array}$ & From 16 to 29 & $\begin{array}{l}\text { Very } \\
\text { high }\end{array}$ & $\begin{array}{c}\text { Brayton cycle, } \\
\text { Sterling } \\
\text { Engine \& } \\
\text { Steam Rankine. }\end{array}$ \\
\hline LFRs & $\begin{array}{l}\text { From } 5 \\
\text { to } 250\end{array}$ & From 8 to 12 & Low & $\begin{array}{c}\text { Steam Rankine } \\
\text { \& Organic } \\
\text { Rankine. }\end{array}$ \\
\hline PTCs & $\begin{array}{c}\text { From } 10 \\
\text { to } 100\end{array}$ & From 10 to 16 & Low & Steam Rankine \\
\hline
\end{tabular}

The electricity production systems from renewable energy are showing a growing trend in terms of use due to the reduction of greenhouse gas emissions and the diversification strategies of countries' energy sources. Therefore, the concentrating solar power (CSP) technologies offer an excellent opportunity to stimulate economic development and create jobs, as Algeria can invest in such solar plants [14]. In addition, Algeria is located between 18 and $36^{\circ}$ north, as its 
area is estimated at $2,381,741 \mathrm{~km}^{2}$ with $70 \%$ being desert. The total annual direct irradiation varies from $2100 \mathrm{kWh} . \mathrm{m}^{-2}$ to more than $\mathrm{kWh} . \mathrm{m}^{-2}$ in southern Algeria [57]. The area where this site is located is considered to be one of the most isolated areas in the world. Algeria is located in the so-called Sun Belt zones, with a sunshine duration of more than 3500 hours/year.

\section{CONCLUSION}

MENA region (Middle East and North Africa) region has some of the best solar fields in the world, as the MENA region has enormous potential for concentrated solar thermal energy compared to the rest of the world, because this technology uses solar beam radiation. There are two types of solar concentrators as follows:

- Linear concentrators: As the beam radiation reception is made along a tube arranged at the focal line of the LFRs or PTCs solar collectors. They are proven technologies, which have significant potential for further development and an acceptable cost;

- Point concentrators: where the receiver in this case is located at the focal point of the HTCs or PDCs solar reflectors.

Generally, advanced technologies, mass production, scale economies and improved operation will allow a reduction in the cost of using solar concentrators in several areas at a competitive level such as the cost of electricity which produces thermally.

Regarding Algeria, all conditions (Solar potential, Earth resources, infrastructure and the political and economic framework) are available to promote sustainable development dependent on the exploitation of the various solar concentrators. Currently, Algeria has embarked on a serious policy to encourage energy transformations towards the exploitation of renewable energy sources, and this matter will serve them in all political and economic aspects with distinction, which will allow the emergence of its positive mark locally and internationally in contributing to sustainable development that contributes to preserving the environment from the various harms issued by traditional sources of energy production.

\section{REFERENCES}

[1] Ghodbane, M., Boumeddane, B., Moummi, N., Largot, S., Berkane, H. (2016). Study and numerical simulation of solar system for air heating. Journal of Fundamental and Applied $\quad$ Sciences, $8(1)$ : $41-60$ http://dx.doi.org/10.4314/jfas.v8i1.3

[2] Kalogirou, S.A. (2004). Solar thermal collectors and applications. Progress in Energy and Combustion Science, 30(3): 231-295. https://doi.org/10.1016/j.pecs.2004.02.001

[3] Kalogirou, S.A. (2009). Solar Energy Engineering: Processes and Systems, 1st ed., Academic Press2009.

[4] Wang, G., Wang, F., Shen, F., Jiang, T., Chen, Z., Hu, P. (2020). Experimental and optical performances of a solar CPV device using a linear Fresnel reflector concentrator. Renewable Energy, 146: 2351-2361. https://doi.org/10.1016/j.renene.2019.08.090
[5] Said, Z., Ghodbane, M., Sundar, L.S., Tiwari, A.K., Sheikholeslami, M., Boumeddane, B. (2020). Heat transfer, entropy generation, economic and environmental analyses of linear fresnel reflector using novel $\mathrm{rGO}-\mathrm{Co}_{3} \mathrm{O}_{4}$ hybrid nanofluids. Renewable Energy, 165(Part 1): 420-437. https://doi.org/10.1016/j.renene.2020.11.054

[6] Rafiei, A., Loni, R., Mahadzir, S.B., Najafi, G., Pavlovic, S., Bellos, E. (2020). Solar desalination system with a focal point concentrator using different nanofluids. Applied Thermal Engineering, 174: 115058. https://doi.org/10.1016/j.applthermaleng.2020.115058

[7] Krishna, Y., Faizal, M., Saidur, R., Ng, K.C., Aslfattahi, N. (2020). State-of-the-art heat transfer fluids for parabolic trough collector. International Journal of Heat and Mass Transfer, 152: 119541. https://doi.org/10.1016/j.ijheatmasstransfer.2020.11954 1

[8] Ghodbane, M., Said, Z., Hachicha, A.A., Boumeddane, B. (2020). Performance assessment of linear Fresnel solar reflector using MWCNTs/DW nanofluids. Renewable $\quad$ Energy, 151: 43-56. https://doi.org/10.1016/j.renene.2019.10.137

[9] Bellos, E., Said, Z., Tzivanidisa, C. (2018). The use of nanofluids in solar concentrating technologies: A comprehensive review. Journal of Cleaner Production, 196:

84-99. https://doi.org/10.1016/j.jclepro.2018.06.048

[10] Hussein, A.K., Ghodbane, M., Said, Z., Ward, R.S. (2020). The effect of the baffle length on the natural convection in an enclosure filled with different nanofluids. Journal of Thermal Analysis and Calorimetry. https://dx.doi.org/10.1007/s10973-020-10300-1

[11] Behar, O. (2018). Solar thermal power plants - A review of configurations and performance comparison. Renewable and Sustainable Energy Reviews, 92: 608627. https://doi.org/10.1016/j.rser.2018.04.102

[12] Calise, F., d'Accadia, M.D., Libertini, L., Vicidomini, M. (2018). Thermoeconomic analysis of an integrated solar combined cycle power plant. Energy Conversion and Management, 171: 1038-1051. https://doi.org/10.1016/j.enconman.2018.06.005

[13] Zhang, Q., Wang, Z., Dub, X., Yu, G., Wu, H. (2019). Dynamic simulation of steam generation system in solar tower power plant. Renewable Energy, 135: 866-876. https://doi.org/10.1016/j.renene.2018.12.064

[14] Ghodbane, M., Bellos, E., Said, Z., Boumeddane, B., Khechekhouche, A., Sheikholeslami, M., Ali, Z.M. (2020). Energy, financial, and environmental investigation of a direct steam production power plant driven by linear fresnel solar reflectors. Journal of Solar Energy Engineering, 143(2): 021008. https://doi.org/10.1115/1.4048158

[15] Ghodbane, M., Boumeddane, B., Said, Z., Bellos, E. (2019). A numerical simulation of a linear Fresnel solar reflector directed to produce steam for the power plant. Journal of Cleaner Production, 231: 494-508. https://doi.org/10.1016/j.jclepro.2019.05.201

[16] Ghodbane, M., Bellos, E., Said, Z., Boumeddane, B., Hussein, A.K., Kolsi, L. (2020). Evaluating energy efficiency and economic effect of heat transfer in copper tube for small solar linear Fresnel reflector. Journal of Thermal Analysis and Calorimetry. https://doi.org/10.1007/s10973-020-09384-6 
[17] Ghodbane, M., Boumeddane, B., Said, N. (2016). Design and experimental study of a solar system for heating water utilizing a linear Fresnel reflector. Journal of Fundamental and Applied Sciences, 8(3): 804-825. http://dx.doi.org/10.4314/jfas.v8i3.8

[18] Ghodbane, M., Boumeddane, B. (2017). A parabolic trough solar collector as a solar system for heating water: a study based on numerical simulation. International Journal of Energetica (IJECA), 2(2): 29-37.

[19] Ghodbane, M., Boumeddane, B., Said, N. (2016). A linear Fresnel reflector as a solar system for heating water: Theoretical and experimental study. Case Studies in Thermal Engineering, 8(C): 176-186, http://dx.doi.org/10.1016/j.csite.2016.06.006

[20] Zhu, G., Wendelin, T., Wagner, M.J., Kutscher, C. (2014). History, current state, and future of linear Fresnel concentrating solar collectors. Solar Energy, 103: 639652. http://dx.doi.org/10.1016/j.solener.2013.05.021

[21] Ghodbane, M., Boumeddane, B., Khechekhouche, A., Benmenine, D. (2020). Study of a solar air conditioning system with ejector. International Journal of Energetica, 5(1): 14-21. http://dx.doi.org/10.47238/ijeca.v5i1.115

[22] Bellos, E. (2019). Progress in the design and the applications of linear Fresnel reflectors - A critical review. Thermal Science and Engineering Progress, 10: 112-137. https://doi.org/10.1016/j.tsep.2019.01.014

[23] Pulido-Iparraguirre, D., Valenzuela, L., SerranoAguilera, J.J., Fernández-García, A. (2019). Optimized design of a linear fresnel reflector for solar process heat applications. Renewable Energy, 131: 1089-1106. https://doi.org/10.1016/j.renene.2018.08.018

[24] Fernandez-Garcıa, A., Zarza, E., Valenzuela, L., Perez, M. (2010). Parabolic-trough solar collectors and their applications. Renewable and Sustainable Energy Reviews, 14: 1695-1721. https://doi.org/10.1016/j.rser.2010.03.012

[25] Pytilinski, J.T. (1978). Solar energy installations for pumping irrigation water. Solar Energy, 21(4): 255-262. https://doi.org/10.1016/0038-092X(78)90001-4

[26] Barlev, D., Vidu, R., Stroeve, P. (2011). Innovation in concentrated solar power. Solar Energy Materials and Solar Cells, 95(10): 2703-2725. https://doi.org/10.1016/j.solmat.2011.05.020

[27] Ma, T., iRen, T., Chen, H., Zhub, Y., Li, S., Ji, G. (2019). Thermal performance of a solar high temperature thermochemical reactor powered by a solar simulator. Applied Thermal Engineering, 146: 881-888. https://doi.org/10.1016/j.applthermaleng.2018.10.025

[28] Bai, Z., Liu, Q., Lei, J., Jin, H. (2017). Investigation on the mid-temperature solar thermochemical power generation system. Energy Procedia, 143: 649-655. https://doi.org/10.1016/j.egypro.2017.12.741

[29] Yadav, D., Banerjee, R. (2016). A review of solar thermochemical processes. Renewable and Sustainable Energy Reviews, 54: 497-532. https://doi.org/10.1016/j.rser.2015.10.026

[30] Environmental-Solar-System, Parabolic Solar Trough Thermal Water Heater. https://www.parabolicsolartrough.com/wpcontent/uploads/2017/02/Sun-solar-map-1.jpg.

[31] Aziz, J.A., Augeard, A., Cabriel, C., Berre, C.L., Pan, M., Yang, X. (2014). Concentrateurs solaires et production électrique, Institut National des Sciences Appliquées de Rouen (INSA). Département Sciences et Techniques pour L’ingénieur, 685 Avenue de L’université BP 0876801 Saint-Etienne-Du-Rouvray.

[32] Silvi, C. (1980). ISES-ITALIA Section of the International Solar Energy Society (1964-1980). ISESItalia (1964-1980), pp. 235-258.

[33] Thuillier, P. (1979). Une énigme: Archimède et les miroirs ardents. Recherche (La) Paris, 444-453. http://pascal-

francis.inist.fr/vibad/index.php?action=getRecordDetail \&idt $=12659807$.

[34] Library, S.P. (2020). Lavoisier's solar furnace. https://www.sciencephoto.com/media/363956/view/lavo isier-s-solar-furnace.

[35] Thombare, D.G., Verma, S.K. (2008). Technological development in the Stirling cycle engines. Renewable and Sustainable Energy Reviews, 12(1): 1-38. https://doi.org/10.1016/j.rser.2006.07.001

[36] Soulen, R.J. (1996). James Dewar, his flask and other achievements. Physics Today, 49(3): 32-37. https://doi.org/10.1063/1.881490

[37] Egyptophile, L'Éégypte: une histoire d'énergie solaire. https://egyptophile.blogspot.com/2015/04/legypte-unehistoire-denergie-solaire.html, accessed on Jun. 20, 2020.

[38] Dabija, A.M. (2020). From Theory to Practice and All the Way Back. Designing with The Sun. In: Visa I., Duta A. (eds) Solar Energy Conversion in Communities. Springer Proceedings in Energy. Springer, Cham. https://doi.org/10.1007/978-3-030-55757-7_36

[39] Grange, B., Dalet, C., Falcoz, Q., Siros, F. (2014). A. ferrière, simulation of a hybrid solar gas-turbine cycle with storage integration. Energy Procedia, 49: 1147-1156. https://doi.org/10.1016/j.egypro.2014.03.124

[40] Wikipédia, THÉMIS solar power plant. https://commons.wikimedia.org/wiki/File:Th\%C3\%A9 mis.jpg? uselang=fr, accessed on Jun. 16, 2020.

[41] Saghafifar, M., Gadalla, M., Mohammadi, K. (2019). Thermo-economic analysis and optimization of heliostat fields using AINEH code: Analysis of implementation of non-equal heliostats (AINEH). Renewable Energy, 135: 920-935. https://doi.org/10.1016/j.renene.2018.12.060

[42] Pfahl, A., Coventry, J., Röger, M., Wolfertstetter, F., Vásquez-Arango, J.F., Gross, F., Arjomandi, M., Schwarzbözl, P., Geiger, M., Liedke, P. (2017). Progress in heliostat development. Solar Energy, 152: 3-37. https://doi.org/10.1016/j.solener.2017.03.029

[43] Collado, F.J., Guallar, J. (2013). A review of optimized design layouts for solar power tower plants with campo code. Renewable and Sustainable Energy Reviews, 20: 142-154. http://dx.doi.org/10.1016/j.rser.2012.11.076

[44] Manikandan, G.K., Iniyan, S., Goic, R. (2019). Enhancing the optical and thermal efficiency of a parabolic trough collector - A review. Applied Energy, 235: https://doi.org/10.1016/j.apenergy.2018.11.048

[45] Soltani, S., Bonyadi, M., Avargani, V.M. (2019). A novel optical-thermal modeling of a parabolic dish collector with a helically baffled cylindrical cavity receiver. Energy, 168: 88-98. https://doi.org/10.1016/j.energy.2018.11.097

[46] Pheng, L.G., Affandi, R., Ab-Ghani, M.R., Gan, C.K., Jano, Z., Sutikno, T. (2014). A review of parabolic dishstirling engine system based on concentrating solar power. TELKOMNIKA, 12(4): 1142-1152. http://dx.doi.org/10.12928/TELKOMNIKA.v12i4.1132 
[47] Coventry, J., Andraka, C. (2017). Dish systems for CSP. Solar Energy, 152: 140-170. https://doi.org/10.1016/j.solener.2017.02.056

[48] Said, Z., Ghodbane, M., Hachicha, A.A., Boumeddane, B. (2019). Optical performance assessment of a small experimental prototype of linear Fresnel reflector. Case Studies in Thermal Engineering, 16: 100541. https://doi.org/10.1016/j.csite.2019.100541

[49] Silvi, C. (2009). The pioneering work on linear Fresnel reflector concentrators (LFCs) in Italy. In: S. Paces (Ed.) 15th Solar Paces Conference, Solar Power and Chemical Energy Systems, Berlin, Germany.

[50] Ghodbane, M. (2017). Étude et optimisation des performances d'une machine de climatisation a éjecteur reliée à un concentrateur solaire Département de génie Mécanique Université Saad Dahleb, Blida 1, Algérie 2017, p. 200. https://www.ccdz.cerist.dz/admin/notice.php?id $=00000$ 000000000862468000841.

[51] Bellos, E., Tzivanidis, C., Papadopoulos, A. (2019). Enhancing the performance of a linear Fresnel reflector using nanofluids and internal finned absorber. Journal of Thermal Analysis and Calorimetry, 135(1): 237-255. https://doi.org/10.1007/s10973-018-6989-1

[52] Bellos, E., Tzivanidis, C. (2018). Multi-criteria evaluation of a nanofluid-based linear Fresnel solar collector. Solar Energy, 163: 200-214. https://doi.org/10.1016/j.solener.2018.02.007

[53] Ghodbane, M., Boumeddane, B. (2017). Optical modeling and thermal behavior of a parabolic trough solar collector in the Algerian Sahara. Modelling, Measurement and Control B, 86(2): 406-426. https://doi.org/10.18280/mmc_b. 860207
[54] Lamba, D.K. (2012). A review on parabolic trough type solar collectors: Innovation, applications and thermal energy storage. The National Conference on Trends and Advances in Mechanical Engineering, YMCA University of Science \& Technology, Faridabad, Haryana, pp. 90-99.

[55] Ericsson, J. (1884). The sun motor and the sun's temperature. $\quad$ Nature, 29: 217-219. https://dx.doi.org/10.1038/029217a0

[56] Fernández-García, A., Zarza, E., Valenzuela, L., Pérez, M. (2010). Parabolic-trough solar collectors and their applications. Renewable and Sustainable Energy Reviews, 14(7): 1695-1721. https://doi.org/10.1016/j.rser.2010.03.012

[57] Ghodbane, M., Boumeddane, B. (2016). Estimating solar radiation according to semi empirical approach of PERRIN DE BRICHAMBAUT: Application on several areas with different climate in Algeria. International Journal of Energetica, 1(1): 20-29.

\section{NOMENCLATURE}

$\begin{array}{ll}\text { CLFR } & \text { Compact Linear Fresnel Reflector } \\ \text { DNI } & \text { Direct Normal Irradiance, W.m }{ }^{-2} \\ \text { EDF } & \text { Electricity of France } \\ \text { HFCs } & \text { Heliostat Field collectors } \\ \text { LCR } & \text { Local Concentration Ratio } \\ \text { LFRs } & \text { Linear Fresnel Reflectors } \\ \text { MDA } & \text { McDonnell Douglas Aerospace Corporation } \\ \text { PDCs } & \text { Parabolic Dish collectors } \\ \text { PTCs } & \text { Parabolic trough collectors } \\ \text { SBP } & \text { Schlaich Bergermann and Partner }\end{array}$

